\title{
WILSON'S DISEASE PRESENTING AS HEMOLYTIC ANEMIA
}

\author{
Ritu Mital ${ }^{1}$, Priyanka Gupta ${ }^{2}$, Aditya Bhatt ${ }^{3}$
}

\section{HOW TO CITE THIS ARTICLE:}

Ritu Mital, Priyanka Gupta, Aditya Bhatt. "Wilson's Disease Presenting as Hemolytic Anemia". Journal of Evolution of Medical and Dental Sciences 2015; Vol. 4, Issue 17, February 26; Page: 2984-2987,

DOI: $10.14260 /$ jemds/2015/431

ABSTRACT: BACKGROUND: Hemolytic anemia as the first presentation of Wilson's disease is extremely rare. CASE CHARACTERISTICS: A 4 year old girl of Wilson's disease presented with jaundice, anemia, abdominal distension and history of melena and hematuria. OBSERVATION: A diagnosis of Wilson's disease was made, and she was put on d-penicillamine and zinc orally. OUTCOME: Marked improvement was noticed at1month follow up. MESSAGE: Wilson's disease should be considered in any child presenting with haemolytic anemia with liver disease.

KEYWORDS: Hepatolenticular degeneration, Kayser-Fleischer rings, d- penicillamine.

INTRODUCTION: Wilson's disease is a genetic disorder of copper handling affecting mainly the liver but also the brain, eyes and kidneys. ${ }^{1}$ This disease has a worldwide prevalence of approximately 30 affected individuals per million of population. ${ }^{2}$ The gene for Wilson's disease (ATP7B) has been mapped to chromosome 13(13q14.3). ${ }^{3}$ The usual age of presentation is between 5-35 years. ${ }^{4}$ The spectrum of Wilson's disease ranges from asymptomatic hepatomegaly to acute liver failure but hemolytic anemia as a presenting feature is rare. Hemolytic anemia is a recognized but uncommon $(10-15 \%)$ complication of this disease. ${ }^{5}$ We report here a case of wilsons disease who presented to us with anemia and jaundice and after an exhaustive work up, the diagnosis was confirmed to be Wilson's disease.

CASE REPORT: A 4 years old girl presented with fever, jaundice, anemia and abdominal distension for two months. History of haematuria and malena was also present. There was no history of clay coloured stools, rashes, diarrhoea, hematemesis, abnormal movements, passage of worms in stool. No similar illness or any hospitalisation had occurred in the past. There was no history of similar illness in other siblings. Prior to her presentation to us, she had been admitted in some other hospital for 6 days where she was managed as a case of septicaemia and had one blood transfusion but could not improve and hence was referred to our setting.

The child was highly irritable at the time of admission. Head to toe examination revealed dry and lustreless hair; icterus and pallor were present, teeth were brown stained and tongue was coated. The skin was dry and scaly. Per abdomen examination revealed distended abdomen with hepatomegaly- $2 \mathrm{~cm}$ below costal margin and liver span of $9 \mathrm{~cm}$, splenomegaly $1 \mathrm{~cm}$ below costal margin and mild ascites with presence of shifting dullness. Initial work up showed Hb- 5.5 gm\%, platelet count- $30,000 / \mathrm{mm},{ }^{3}$ total bilirubin- $3.3 \mathrm{mg} / \mathrm{dl}$, moderately elevated liver enzymes and deranged coagulation profile (INR-1.67, PT-18 sec). General blood picture showed significant number of microcytic hypochromic cells, tear drop cells and pencil cells.

These investigations pointed towards haemolytic anemia. Direct Coombs' test, malarial antigen test and Widal test were negative. HbsAg and HCV test were also negative. Finally, work up for Wilsons Disease was done which showed that urinary copper was raised (100ug/24hours) and 


\section{CASE REPORT}

Serum ceruloplasmin was low $(19.8 \mathrm{mg} / \mathrm{dl})$. $(19.8 \mathrm{mg} / \mathrm{dl})$. Liver biopsy was performed after 5 transfusions of fresh frozen plasma that reported cirrhotic changes. Kayser-Fleischer (KF) ring was negative. KF ring is usually present in patients with neurological abnormalities but may be absent in $40-60 \%$ of those with hepatic form. ${ }^{6}$

The diagnosis of Wilson's disease was made and the patient was started on d-penicillamine therapy and zinc. She improved dramatically within 15 days of treatment and after a follow up of 2 months her abdominal girth has decreased to $42 \mathrm{~cm}$ from $51 \mathrm{~cm} \mathrm{~S}$. bilirubin and liver enzymes are almost normal (S. Bilirubin-1.1; SGOT-44U/L; SGPT-55U/L)and coagulation profile is within normal limits. (INR=1)

DISCUSSION: Copper is one of the essential metals of the body that serves as a cofactor for many proteins. Wilson's disease, an autosomal recessive disorder, is also known as hepatolenticular degeneration. It is a familial, lethal neurological disease that can be accompanied by chronic liver disease leading to cirrhosis. ${ }^{7}$ The condition is due to a genetic defect (Mutation) in the Wilsons disease protein gene (ATP7B). Since liver and brain are the main sites of copper accumulation, the patient usually presents with liver disease and neuropsychiatric symptoms. However, this disease rarely presents as haemolytic anemia as the first symptom. ${ }^{4}$

The gene for Wilson's disease (ATP7B) has been mapped on chromosome 13(13q14.3). ${ }^{3}$ The usual age of presentation is between 5-35 years. ${ }^{4}$ Haemolytic anemia as the first presentation of Wilson's disease is extremely rare. The exact mechanism by which hemolysis occurs is not known. Damage in the form of liver necrosis can release free copper ions in blood, that can cause oxidative damage like hemolysis. ${ }^{8}$ It also increases free radical production that also contributes to hemolysis. Recently, it has been proposed that free copper ions activate acid sphingomyelinase and release chemicals that damage RBCs. ${ }^{9}$

Diagnosis is confirmed by liver Copper concentration estimation.

Our case presented as anemia and jaundice with hepatosplenomegaly. She was neurologically normal. General blood picture showed haemolytic picture. Liver functions were deranged and the patient received multiple transfusions of FFP. Diagnosis was confirmed on the basis of low serum ceruloplasmin and high urinary 24 hour copper. Liver biopsy showed cirrhotic changes. Acute intravascular hemolysis is due to destruction of erythrocytes by a sudden flux of copper ions from the necrosing hepatocytes. ${ }^{10}$ Hemolysis of similar type is reported in humans in accidental copper poisoning. KF ring may be absent.

CONCLUSION: Thus, we conclude that Wilson's disease should be kept in mind when the presenting feature is hemolytic anemia with chronic liver disease and Wilson's disease can present even below 5 years of age.

\section{REFERENCES:}

1. Roberts EA. Wilson's Disease. In: Dooley JS, Lok ASF, Burroughs AK, Heathcote EJ, editors. Sherlock's Diseases of the Liver and Biliary System. 12th Ed. West Sussex: Wiley- Blackwell Publishing; 2011.

2. Frydman M. Genetic aspects of Wilson disease. J Gastroenterol Hepatol 1990:5:483-490. 


\section{CASE REPORT}

3. Kasper DL, Braunwald E, Hauser S, Longo D, Jameson JL, Fauci AS (2005) Harrison's principles of internal medicine, 16th edn. McGraw Hill, New York.

4. Roberts EA, Schilsky MLA practice guideline on Wilson disease. Hepatology 2003; 37: 1475-92.

5. Grudeva-Popova JG, Spasova MI, Chepileva KG, Zaprianov ZH (2000) Acute hemolytic anemia as an initial clinical manifestation of Wilson's disease. Folia Med (Plovdiv) 42(2): 42-46.

6. Frommer D, Morris J, Sherlock S et al. Kayser -Fleischer -like rings in Patients without Wilson's disease. Gastroenterology 1977; 72: 1331-1335.

7. Wilson SAK. Progressive lenticular degeneration: a familial nervous disease associated with cirrhosis of the liver. Brain 1912; 34: 295-507.

8. Attri S, Sharma N, Jahagirdar S, Thapa BR, Prasad R. Erythrocyte metabolism and antioxidant status of patients with Wilson disease with hemolytic anemia. Pediatr Res 2006; 59: 593-7.

9. Lang PA, Schenck M, Nicolay JP, et al. Liver cell death and anemia in Wilson disease involve acid sphingomyelinase and ceramide. Nature Medicine 2007; 13: 164-70.

10. McIntyre N, Clink HM, Levi AJ et al. Hemolytic anemia in Wilson's disease. N. Engl. J. Med. 1967; 276: 439-444.

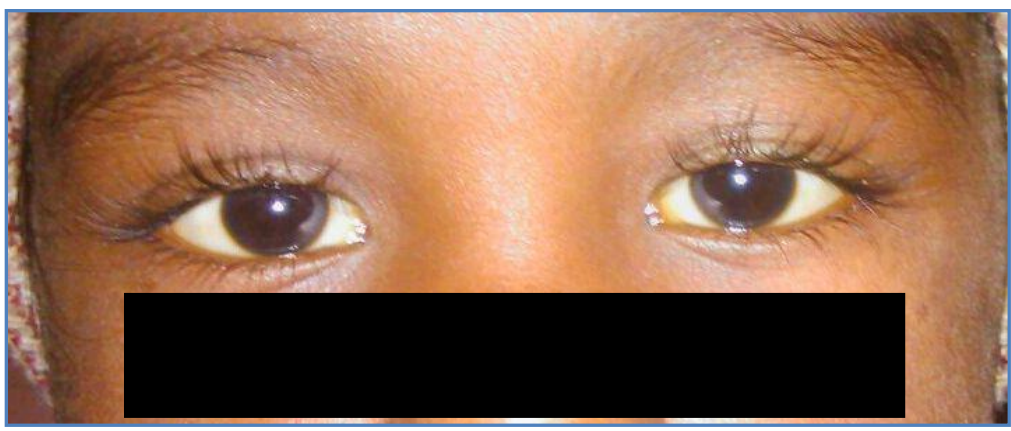

Fig. 1: Icterus

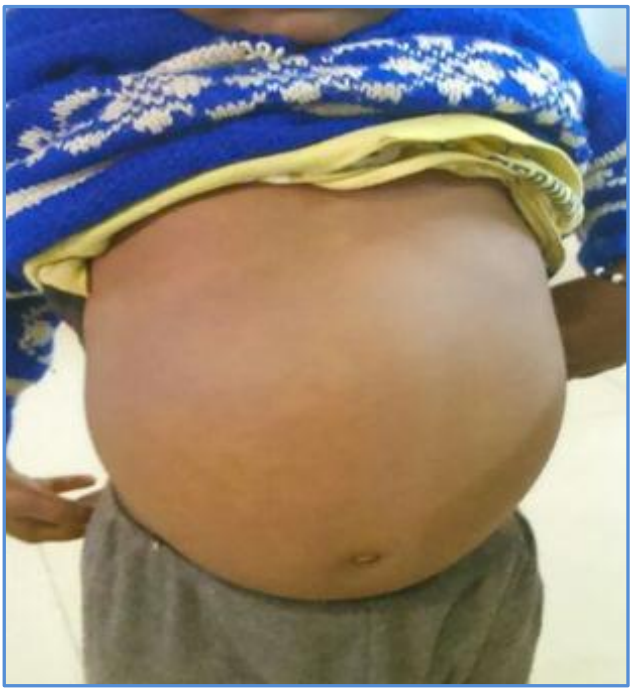

Fig. 2: Ascites

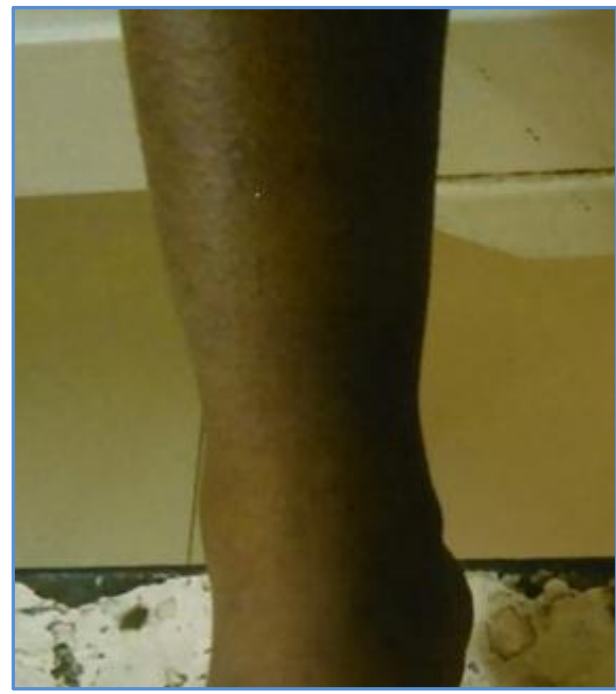

Fig. 3: Coarse Skin 


\section{AUTHORS:}

1. Ritu Mital

2. Priyanka Gupta

3. Aditya Bhatt

\section{PARTICULARS OF CONTRIBUTORS:}

1. Assistant Professor, Department of Paediatrics, LLRM Medical College, Meerut.

2. $2^{\text {nd }}$ Year Junior Resident, Department of Paediatrics, LLRM Medical College, Meerut.

3. $3^{\text {rd }}$ Year Junior Resident, Department of Paediatrics, LLRM Medical College, Meerut.

FINANCIAL OR OTHER COMPETING INTERESTS: None

\section{NAME ADDRESS EMAIL ID OF THE} CORRESPONDING AUTHOR:

Dr. Ritu Mital,

B-13, Damodar Colony,

Garh Road, Meerut-250004,

U. P.

E-mail: mitalritu15@gmail.com

Date of Submission: $11 / 02 / 2015$.

Date of Peer Review: 12/02/2015.

Date of Acceptance: 13/02/2015.

Date of Publishing: 25/02/2015. 